\title{
Brain imaging skewed fMRIの解析方法に要注意
}

\author{
Alison Abbott Nature Vol. 458(1087)/30 April 2009
}

有力な専門誌に発表された 2008 年の神 経画像関係の研究論文のほぼ半数に、意 図せずに偏ってしまったデータが紛れ込ん でおり、科学的結論が歪められるおそれ がある、と米国立精神衛生研究所 (メリー ランド州ベセズダ）の科学者が報告した。

Nature はこの分野の複数の専門家に意 見を求めたが、いずれも、研究手法の誤 りがこれほどの規模で広がっていること、 また、厳格に実施されていると思われて きた有力誌の査読制度をすり抜けてしまっ たことに驚きを隠さなかった。

Nikolaus Kriegeskorte. Chris Bakerらは、トップクラスの専門 5 誌 (Nature、Science、Nature Neuroscience、 Neuron、The Journal of Neuroscience) に 2008 年に発表された、機能的磁気共鳴画 像法 (fMRI) による研究論文 134 本を分 析した。その結果は、Nature Neuroscience の 2009 年 5 月号に発表されたが (N. Kriegeskorte et al. Nature Neurosci. 12, 535-540；2009)、対象論文のうちの 57 本で、いわゆる非独立な選択的解析（nonindependent selective analysis) が 一度以上行われていることが判明した。

解析が「非独立」とされるのは、仮説 を得る際に条件を設定する時と、その仮 説を実証する時に同じデー夕を使う場合で ある。もちろんこれは正しくない。ただし 「我々は、こうした研究論文が最終的に 誤った結論を導き出している、と言ってい るわけではありません。誤りが重大なもの とならない場合もあり、不明瞭さが生じて います」とBaker。

「今回の出来事は、有力専門誌の査読 の質が十分でないことを反映しており、各
誌ともその厳格性をきちんと見直す必要が ある」。こう断言するのは、ロンドン大学 ユニバーシティカレッジのウエルカム・ト ラスト神経イメージングセンター（英国） の科学ディレクターKarl Fristonだ。

脳画像研究では、ボクセル (二次元画 像の「ピクセル」に相当する三次元デー 夕の基本単位）を単位として、脳全体か ら大量のデータが得られる。神経科学者 は、被験者が行う課題（例えば顔や静止 画）によって活性化するボクセルを探索し、 関心領域を決め、それを重点的に調べる ことがある。

ところが fMRI データは、もともとノイ ズが多く、偽信号（偽の相関を示すボク セル）が数多く生じる。そうした中で、例 えば、被験者に顔を見つめる課題を出し、 ある特定の脳領域の応答が、静止画を見 つめる課題を出した時に比べてどれほど 強くなるか、といったことを調べるわけだ。 問題が生じるのは、その脳領域を選択す る際と、実験によって生じた影響を定量化 する際に、同じデータを使ってしまう場合。 これが解析の「非独立」という誤りだ。

「最初の選択過程で使ったデータとは別 個のデー夕群を使って、実験結果を解析す ること（解析の独立性を確保すること）が 決定的に重要なのです。データ全体を半 分に分け、一方をボクセルの選択に使っ て、もう一方を、選択したボクセルにお ける応答の解析に使うことでもいい」と Baker は指摘する。

これと似たタイプの誤りに関して、マ サチューセッツ工科大学（米国ケンブリッ ジ）のEdward Vulらの研究がある（E. Vul et al. Perspect. Psychol. Sci. 4, 274-
290；2009)。今年に入って、この研究 論文のプレプリントで、“魔術的な相関” という表現や、循環論法的な解析を行っ たとされる研究者の名前が記載されてい ることがわかり、関係分野は大騷ぎになっ た (Nature 457, 245; 2009 参照)。

しかし今回の論文では、研究者の個人 名は出していない。「誤りがあまりにも常 態化しているため、名前の公表はしませ んでした。それに、個人レベルで論じる理 由もありません。問題を浮き彫りにして、 罠に陥る人を減らすことが我々の意図で す」とBaker。

「この新論文はさほど物議を醸すとは思 いませんが、問題をより深刻に捉えるべき かもしれません。この選択の偏りという問 題には、統計学の特別な知識が要るわけ ではありません。従来の正しい実験手順 に従うだけでよいのです。決して難しいこ とではありません」とFristonは語る。

Bakerは、循環論法的な方法による誤 りが、神経科学の多くの分野に忍び込ん でいる点を指摘する。「この問題は、電気 生理学の単一ニューロン活動記録、脳波 記録、遺伝子マイクロアレイ解析、それ に行動デー夕にさえ同様に当てはまるので す」特に影響を受けやすいのが fMRI デー タというわけだ。理由は、デー夕量が膨大 なために複雑な解析が必要なこと、そし て、訓練を受けていない専門外の研究者 が数多く新規参入していることである。

「数年でも fMRI 解析を経験すれば、こ の問題は過去のものとなります。しかし、 急速に学習していく人々は、少数派なが ら常に相当数存在する状態が続くと思いま す」とFristonは語っている。 